\title{
New opportunities in common security and defence policy: Joining PESCO
}

\author{
Christian Leuprecht \\ Royal Military College \\ christian.leuprecht@rmc.ca \\ Rhianna Hamilton \\ Queen's University \\ 16rmeh@queensu.ca
}

\begin{abstract}
Responding to concerns about burden-sharing and aiming to improve internal defence cooperation, act more quickly and harness resource synergies, the European Union (EU) initiated the Permanent Structured Cooperation (PESCO) in 2017. PESCO, however, is controversial. On the one hand, the United States (US) wants greater burden-sharing by European allies whilst concerned about greater European military autarky that would undermine US influence over NATO, Europe/EU and EU member states. On the other hand, at least one European NATO ally wants to leverage PESCO precisely as an instrument to shore up European "strategic autonomy". This tension over competing European defence futures leaves participation by third countries in limbo. Arguably, third-country participation would hinder greater European defence autarky. The article makes the case for the mutual benefits of third-country participation, focusing on Canada. Canada has a major stake in the outcome. NATO is Canada's most important multilateral institution and Europe is Canada's second-most important strategic partner, after the US. Canada's unequivocal strategic interests in Europe have long informed its expeditionary priorities -- from the two world wars, when Canada coming to Europe's defence long before the US proved existential for both parties, to nowadays. Since the 1970s, Canada and Europe have worked consistently together bilaterally beyond NATO to advance regional stability and mutual security interests. Canada's and Europe's defence futures are thus interdependent. Excluding third countries from participating in PESCO would have detrimental consequences for Canadian, European and transatlantic defence interests. In contrast, with third country participation, PESCO will be instrumental to effective transatlantic and transeuropean defence integration.
\end{abstract}

Key words: Canada, Defence, European Union, NATO, PESCO

\section{Introduction}

National security and defence are among the most fiercely guarded areas of national jurisdiction, in part because they protect the state from existential threats, and in part because a series of ancillary benefits accrue to the state, such as innovation, economic growth, jobs, and so forth. As a result, collaboration, coordination and cooperation in defence can prove difficult and needs to be incentivized. This is in keeping with balance of threat theory and the economic theory of alliances, which explain why smaller states generally ally with a larger power: for protection and to free-ride on security guarantees (Ringsmose, 2012, p. 107). Such collective action problems have famously attended 
European members of the North Atlantic Treaty Organization (NATO) since the inception of the Alliance 70 years ago with special focus allocated to issues like military mobility (Tardy, 2018, p. 3). So, many Europeans were bewildered when, in May 2019, the US Pentagon formally expressed its disapproval of the Permanent Structured Cooperation (PESCO) and the European Defence Fund (EDF) in a pejorative letter addressed to the EU's then foreign-policy chief, Federica Mogherini. The letter expressed concerns that these functional arrangements would "produce duplication, noninteroperable military systems, diversion of scarce defence resources and unnecessary competition between NATO and the EU" (Brzozowski, 2019, online). This apparent contradiction - between the major power's concerns about levels of cooperation and competition on the one hand, and strategic use of defence resources on the other - is telling and instructive. The US has a balance to strike: between an enduring interest in having allies shoulder more of the burden, but without inadvertently engendering greater allied military autarky that might compromise US influence over its allies.

The EU forged its Common Defence and Security Policy (CDSP) in 2003 in the wake of the Lisbon Treaty, which spawned a series of external strategic partnerships with nonEU member countries. In 2017, the EU announced PESCO as a means to improve internal defence cooperation, act more quickly, and synergistically leverage EU resources among 25 of 28 EU member states (Biscop, 2012, p. 1305): the UK, Denmark and Malta opted out of this trans-European arrangement. PESCO is complemented by the EDF whose strategic aim is to provide funding to encourage medium and smaller member states to play along with PESCO (Biscop, 2012, p. 1305). The Trump administration's aforementioned reaction to PESCO illustrates the limits of burden-sharing within the NATO alliance: while it is to the US's benefit for European allies improve their cooperation, it is not in the US interest for Europe to become an autarkic military actor as that would compromise US influence over NATO as well as European military affairs. This article takes up this controversy in the context of third-country participation in PESCO, using Canada as a critical case study.

First, the article briefly explains PESCO and EDF, and situates them in the context of the CDSP, transatlantic and trans-European relations. Then the article situates the EDF and PESCO more specifically in the context of Canada-EU relations in general, and the Canada-EU Strategic Partnership Agreement more specifically. Finally, the article explains the prospective participation of third parties in both the EDF and PESCO from the perspective of Canadian grand strategy, bilateral relations between Canada and select EU member countries, and EU grand strategy. The article concludes by considering Canadian participation in PESCO and EDF in the context of decades of existential ties between Canada and Europe. The nexus of that transatlantic and transEuropean defence relationship transcends mere transactional and instrumental relations of mutual benefit and is instead at the very crux of shared grand strategic objectives that are shaped by mutual co-dependence on the US security umbrella and extended nuclear deterrence.

\section{Context}

The strategic uncertainty sown by the Trump administration about America's enduring commitment to the defence of common regional and international interests has been galvanizing closer synergies among non-US allies (Leuprecht et al., 2019, p. 164). The election of Donald Trump as the 'Disruptor in Chief' is symptomatic of the US stepping back from global defence initiatives (Allison 2018, p. 132). Although he would be loath to 
admit it, Trump's approach is actually marked by considerable continuity with Obamaera initiatives in which the US has maintained a consistent policy of "pragmatic realism", where the US chooses to respond to global crises as a function of domestic factors (Dombrowski Reich, 2018, p. 57). The 'silver lining' here is how waning trust in the US's commitment is emancipating domestic and trans-European self-consciousness and autonomy in doubling down on multilateral relations (Dombrowski Reich, 2018, p. 57). In response, the trans-European relationship is morphing: from a bilateral hub-andspoke model centred on Washington, DC, to a denser multiplayer network. The emergent fusion of transatlantic and trans-European relations has been accelerated by the Trump administration's pursuit of accommodating immediate, narrow existential US interests, even if it comes at the expense of allies, such as confrontation with the EU over tariffs and barriers. The priority the US accords to Chinese and Russian threats above European defence contributes further to divergence from EU member states (Colby and Mitchell, 2020, pp. 118-130).

Member states of NATO, individually and collectively, are finding their foreign, security and defence policy increasingly decoupled from that of the US for the first time since the end of WWII and the rise of the US from a regional power to the preeminent superpower over the course of the $20^{\text {th }}$ century. Tranatlanticism had always been as much about extended US deterrence - the "Empire by invitation" (Lundestad, 1986, pp. 263-277) as about the claim to superpower status: in modern times, that status has inextricably been linked to the power that is able to dominate Europe. At the same time, the emergent multiplayer network structure among US allies suggests that the relationship among the non-US members of the Alliance, among Canada and the EU, and between Canada and select EU member states, is actually becoming more resilient.

PESCO exemplifies that emergent multiplayer network: it is the first binding security commitment within the EU, including 25 EU self-enlisted member states (Biscop, 2012, p. 1306). PESCO is less clear-cut than the EDF but has the potential to use resources more effectively (European Commission, 2019). Whereas PESCO is funded by states and supported by pre-existing institutions, the EDF has dedicated funding diverted from other EU projects. Where the EDF fosters research and innovation, PESCO is operational in nature. PESCO focuses on the development of shared defence capabilities with projects such as military, cyber and disaster relief. As of November 2019, PESCO had 47 projects across seven categories: Training, Facilities; Land, Formations Systems; Maritime; Air, Systems; Cyber C4ISR; Enabling, Joint; and Space (cf. Appendices A and B). Within each category multiple projects are in progress with member states choosing to participate in initiatives based on factors such as the availability of armed forces, capabilities, and national defence priorities. However, third-country participation is an issue yet to be resolved.

The European Defence Agency (EDA) offers a model for third-country participation. For PESCO, however, that model is suboptimal. The EDA and EDF are already open to thirdcountry engagement on an exceptional basis, provided involvement falls within a procurement or contractual framework. However, this necessarily precludes ongoing contracts and the long-term and stable involvement of third-country participation (European Parliament, 2019). By contrast, PESCO opens the opportunity to harness defence synergies more effectively and precisely by capitalizing on EU resources, collaborating with NATO, and enabling member-state capabilities to be shared. The scale of PESCO's influence thus makes it a key player in defence relationships both within and beyond the EU. 
PESCO, then, is not just a mere instrument to improve cooperation, but also holds out the promise of a new dawn in transatlantic and trans-European relations. That dawn harbours significant opportunity for improved burden-sharing; but it also harbours considerable risk. On the one hand, PESCO could eventually pave the way for the EU to mature into an autarkic military actor that could go it alone in defence rather than with other allies, such as Canada or the U.S. On the other hand, PESCO may end up alienating the US from the EU and NATO, rather than generating synergies, efficiencies and effectiveness that enhance collective burden-sharing. There is clear potential for the EDF and PESCO to divide burden sharing, provide effective and widespread defence against cyber-threats, and facilitate more specific communication between EU and NATO institutions (Lété, 2019, p. 39). Views on the competing aims of PESCO differ among EU member states: as an enabler of trans-European synergies within the transatlantic relationship - or outside it. The difference in views is a function of competing conceptions of "strategic autonomy," as French president Emmanuel Macron likes to call it: dealignment or realignment - the EU as a more autonomous actor beyond transatlantic relations, or PESCO as a means of bolstering the EU as a strategic actor within the transatlantic and trans-European framework (The Economist, 2019). That divergence necessarily makes the quality and quantity of third-country participation controversial.

\section{Defence cooperation}

The CDSP is agnostic on this matter. Its aim is closer defence cooperation among and within the EU. For instance, research, development, innovation and procurement are notoriously complex and expensive; so, cooperation holds out the promise of disproportionate economies of scale (European Defense Agency, 2019). That is especially tempting in times when threat vectors are multiplying, the regional and international security environment is becoming more complex, and budgets are restrained. At the same time, there is little appetite for a European army on a state or institutional level especially among countries within the EU (Mérand, 2008). From the perspective of Canada, the EU's strategic partnership countries and the vast majority of EU member states these are distinct problems, generating greater operational synergies as opposed to working towards a European army. France, by contrast, has long held a very different view that privileges bilateral agreements with the UK over multilateral relationships with the EU and North America (Biscop, 2012, p. 1306). Bilateral agreements provide for benefits to be distributed evenly between the states in question. Given concerns over 'band wagoning' within the EU combined with Brexit negotiations such bilateral agreements will likely become more fashionable. The trend towards bilateralism between European states is exacerbated by the US taking a step back from NATO. With the advent of the Trump administration, Europe has taken on a greater leadership role among the other great powers (Allison, 2018, p. 130). To compensate for diminished credibility, the loss of the UK, and the decreasing American security presence in the region, the EU has rallied around facilitating "strategic autonomy" in defense (Tardy, 2018, p. 2). The focus on "strategic autonomy" has provided a shared goal among EU members and has worked to foster an institutionalized commitment to defence innovation and industry apart from the US influence (Sokolsky 2019, p. 7).

To this end, PESCO aims to enhance European defence cooperation in a way that past frameworks such as the Common Security and Defence Policy (CSDP) and European Security and Defense Policy (ESDP) could not (Biscop, 2012, p. 1305). Furthermore, it builds on the efforts that these initiatives took in facilitating EU autonomy from NATO 
as such a desire emerged in part due to NATO's handling of the various Yugoslav conflicts (Tardy, 2018, p. 1). A closer look reveals that PESCO generates different benefits and complications than past agreements that have aimed to strengthen European defence. First, participation in PESCO is voluntary for EU members, which is meant to avoid commitment problems. Second, the minimal pool of resources available to this voluntary arrangement means that PESCO is set up in a top down fashion that leverages existing EU institutions. Although states do not have to commit their own resources and funding, it is not without pitfalls (Biscop, 2012, p. 1305). Finally, all PESCO agreements that states choose to enter into are legally binding. All 25 members are required to submit a National Implementation Plan (NIP) outlining annual progress to ensure that they are upholding PESCO agreements (European Union, 2019).

The EDF, meanwhile, is a comprehensive defence fund that signals a shift in EU priorities, putting defence at the forefront. The Commission is aiming to use the EDF as a fully-fledged innovative defence base with the capability to expand the EU's "strategic autonomy" (European Union, 2019). To this end, the Commission has committed a modest 13 billion EUR between 2021 and 2027 - about what Portugal spends annually on defence (European Defence Agency, 2019). Member states can increase value by adding to this baseline funding. The specific focus of this investment is research and creation of innovative technology and equipment (European Defence Agency, 2019).

PESCO is meant to facilitate an open-ended form of defence cooperation. Current PESCO initiatives include a cyber response team and possess a specific focus on software (cf. Appendices A \& B); but the bulk of Projects have thus far been about increasing military mobility throughout Europe, especially in collaboration with NATO (Fiott, 2018, p. 314). PESCO's most recent batch of 13 projects are more specific than previously developed initiatives, focusing heavily on innovation and training (cf. Appendix B). Yet, none of these projects involve countries from continents other than Europe (Council of the European Union, 2019). At present, France is concerned that an inclusive PESCO will aggravate collective action problems and thus weaken cooperation, a concern to which Greece, Spain and Germany in particular are sympathetic (Maulny and Di Bernardini 2019, p. 10). Some would like to see case-by-case criteria that can guarantee the support of states with expertise and exclude others that have little value to add (Maulny and Di Bernardini 2019, p. 10). This has a direct bearing on Canada given the significant value-added it has been providing as an eFP Framework nation to Latvian, Baltic and Nordic deterrence. As such, including Canada in PESCO is a ready way for Europe to keep Canada engaged. The main concern about including third-party states is that they may degrade the ability of the EU to make strategic decisions. However, this is hardly a concern with respect to Canada - its interests have long aligned tightly with those of the EU and its member states.

\section{Canada and Europe}

Canada and the EU share goals of combatting terrorism through shared links, promoting international law, sustainable development of shared policies, all with a specific comment to the importance of multilateral organizations in advancing cooperation and addressing challenges (Brunet-Jailly et al. 2018, p. 360). They have a joint interest in international peace and security such as control of weapons of mass destruction, monitoring of circulation of small arms, participation in the international criminal court, combat of terrorism, support to international peace and stability, and cooperation throughout different organizations (Government of Canada, 2018). Canada and the EU 
are committed to improving the effectiveness of the Organization for Economic Cooperation and Development (OECD), NATO and Organization for Security and Cooperation in Europe (OSCE) (Government of Canada, 2016). Specifically, article 15 the Canada-EU Strategic Partnership Agreement addresses knowledge-sharing through innovation and technology (Government of Canada, 2018). The Agreement comes on the heels of the Comprehensive Economic and Trade Agreement (CETA). Canada already participates in a plethora of EU ventures, from the European Space Agency to the European Centre of Excellence for Countering Hybrid Threats. Over the years, Canada has worked closely with Europe on development policy (Rath, 2004, p. 859) and contributed to a host of reconstruction, stabilization, rule-of-law and policing missions run by the EU.

The Strategic Partnership Agreement upgrades current cooperation between Canada and the EU, specifically regarding trade and investment, and furthers a shared focus on security. Many Canada-EU bilateral discussions involve PESCO content such as cyber and military response (European Defence Agency, 2019). At the same time, Canada has a track-record of agreements with the European Defence Agency (EDA), notably through NATO arrangements (European Defence Agency and NATO, 2015).

But common ties and commitment run much deeper. No non-European country carried a heavier death toll on the European battlefields of the two world wars than Canada. It was Canada's early commitment to WWII that helped the UK fend off German invasion. It also allowed the US to use the UK as an eventual staging theatre for the subsequent allied invasion of the continent. Canada had an extensive commitment to Europe during the Cold War in the form of its deployment to Germany. It made a significant contribution to stabilizing the Balkans. And, as of late, Canada has had a significant military footprint in the Middle East and North Africa. This is in part because regional stability is in Canada's interest as conflagration in the Middle East had destabilizing effects on European domestic politics. ${ }^{1}$

For over a century Canada has been resolute in its commitment to European peace and security on the one hand, and to the transatlantic alliance on the other hand - through NATO, as well as through the EU. For Canada, NATO has been first and foremost about security, particularly European security. Irrespective of the government of the day, Canada is a "closest realist". It participates in European missile defence (while having stayed out of Ballistic Missile Defence of the North American continent) and made a Framework Nation commitment to Latvia as part of the enhanced Forward Presence (eFP) along the North-Eastern flank. An unwavering commitment to peace and stability in Europe is integral to Canadian grand strategy for reasons of national as well as collective interest.

Canada saw it as vital to its interests to prevent any single power from dominating Europe - first Germany, against which Canada went to war twice, and then the Soviet Union. As one harsh critic of Canadian engagement in NATO once put it, "In many ways Canada's role in NATO was a form of atonement for our lack of broad foreign policy objectives after the First World War" (Hertzman et al., 1969, p. 15). Having tried to retreat into a state of isolationism after 1918 only to be dragged back into another European war in 1939, Canadians said in 1949 "never again". That is why they were prepared to join in, to contain the Soviet threat before it got out of hand. During the

${ }^{1}$ Discussion about Canada's help to Ukraine in Bendiek and Schenuit (2019, in this Special Issue). 
negotiations that led to the North Atlantic Treaty, one articulate Canadian diplomat noted,

[t]his link across the North Atlantic seems to me to be such a providential solution to so many of our problems that I feel we should go to great length and even incur considerable risk in order to consolidate our good fortune and ensure our proper place in this new partnership (Reid 1977, p. 312)

Canada can do so because it has capacity. Canada fields the eighth-largest military in NATO. Canada ranks among the top 20 militaries in the world (Leuprecht et al., 2019, p. 120). Although within NATO, Canada ranks in the bottom third on military spending as a percentage of GDP, Canada consistently ranks around $15^{\text {th }}$ in the world in in total military expenditure (Tian et al., 2019). This is reflected in Canada's 2019 defence expenditure, totalling at 28810 million Canadian dollars, or 21885 US dollars (Ozawa, 2019, pp. 142-143). In NATO, only the US, the UK, France, Germany and Italy spend more on defence. These countries are all more populous and with larger economies than Canada. On a per capita basis, only the US, Norway, the UK, Denmark, Netherlands, France, Germany and Greece spend more than Canada (Leuprecht et al., 2019, p. 120). Canada has, on occasion, been criticized for spending too little on defence. However, these figures and Canada's contribution to the enhanced Forward Presence in Latvia show such criticism to be misleading. In fact, Canada is one of only five NATO member countries that maintains a full-spectrum military, it is among half a dozen NATO member countries that can field experienced and trusted headquarters capacity, and has a proven track-record to deploy that capacity in support of collective defence, regional stability and international security (NATO, 2017). The capacity that Canada offers is popular, robust, competent and well-equipped. Defence is ultimately about balancing cost, capability and commitment. Canada's 'mantra' has always been not to focus not on expenditure but on capability and commitment instead, since Canada consistently outperforms on both (Leuprecht et al., 2019, p. 121).

And yet, as discussed in the larger public policy context, governments cannot easily escape the dilemmas, problems and paradoxes of defence spending, especially for unanticipated foreign deployments (Leuprecht et al., 2019, p. 121). On the one hand, funds spent on defence are then not available to enhance economic prosperity and social well-being. In domestic politics, there is little electoral payoff to spending on defence relative to the disproportionate payoff for spending on economic growth and social programs. That explains why as a percentage of GDP and overall government expenditure, democracies spend not just very little on defence, by and large, they actually spend (significantly) less on defence than other types of regimes (Leuprecht et al., 2019, p. 122).

On the other hand, NATO collectively accounts for about three quarters of global defence spending (Leuprecht et al., 2019, p. 122). Ergo, democracy needs to be defended; but because democracies tend to be disproportionately prosperous, they can afford to outspend other regimes on defence without breaking the bank. In fact, military spending among democracies is not just instrumental. It is existential to counter a host of risks, the greatest being internal derision, not external aggression.

The risk of greater US unilateralism has loomed since the inception of the Alliance, reflecting US policies of defence prior to WWII (McDougall 1997, p. 139). The current wave of potential retrenchment under the premise of Offshore Balancing would see 
fewer US troops stationed abroad and a greater emphasis on favoured regional powers to check the hostile ones. This is problematic for those countries that rely on NATO for collective defence and may lose out in innovation and security if they take a step back. As such, Canada has an interest in keeping the US engaged, as do all other NATO member countries (Haglund 1990, p. 84). But only a handful of members have capacities analogous to the ones Canada can bring to bear. As such, Canada may not be conspicuous by its presence in PESCO and the EDF, but Canada's absence would certainly be noticed. Canada's firm commitment further entices the US to stay engaged with Europe and in the region at a time when the US appears to be reneging on its European commitments (Elbridge and Mitchell, 2020). The US is more likely to remain committed to Europe when the burden is shared equitably among allies.

The eFP and PESCO enhance burden-sharing by harnessing synergies and economies of scale. Like all countries, the US pursues its self-interest and has always done so. It has always been "America First." The US is so powerful in relative terms that it can afford to make unilateral decisions whilst most allies cannot. Multilateralism becomes a 'default' option for the other allies. By way of example, Canada would never go to war or deploy on its own. It deploys always in coordination with allies, the US first and foremost among them. The US's clout means that decisions made in Washington reverberate strongly with allies. Commitments to collective defence, such as PESCO, are thus also a way for allies (such as Canada) to check the US's unilateralist inclinations. In contrast to the US's hegemony over defence innovation and procurement, PESCO encourages collaboration and cooperation on the one hand, and a balance against the US's hegemony mentioned above on the other.

Indeed, the other institutionalist rationale for NATO has long been to solve commitment problems in the form of easy-riding (not free-riding) (Leuprecht and Sokolsky, 2015, p. 544) among member countries tempted to under-spend on defence and contain the temptation of over-reliance on the US security umbrella. The US has long encouraged European states to strengthen regional defence with the intent of reducing US spending in the area. EU defence has responded with a vigour, to the point where it risks weakening NATO resources rather than reduce them as intended. A trajectory towards greater self-sufficiency offers European countries that remain vested in US defence, such as Germany, with the opportunity to become better equipped to act unilaterally (Sokolsky, 2019, p. 7). PESCO and the EDF will perform an analogous function - provide an incentive for countries to continue to spend on defence and hedge against commitment problems. The risk of subsequent defection is real. During the initial years of the new millennium, European NATO allies reduced their defence budget by some 50 billion Euros collectively. US concerns extend beyond transatlantic countries outside of the EU. These countries benefit from a stronger and more independent Europe yet lose out from a reduced US defence presence. Confronted with the threat of Russian revisionism, trans-European synergies that optimize defence coordination bolster the sort of united front that serves both US and allied interests in the region (Elbridge and Mitchell, 2020).

Canada cares about Europe and its flanks for at least three strategic reasons. First, Canada's prosperity hinges directly on trade, and notably its ability to export natural resources across the world. As Canada develops an increasingly close trade relationship with the EU through agreements such as CETA, threats to resource consumption may depress trade demands. This may counter Canadian strategic interests of expanding trade with Europe. 
Second, aside from Canada's bilateral relationships with the US and its transatlantic NATO partners, Europe is Canada's most important multilateral partner. For strategic reasons, then, Canada is intent on a stable, united, prosperous, harmonious and powerful Europe in general, and the EU in particular. The EU and its member countries are increasingly called upon to solve crises, both within NATO and without. That makes the EU an emergent superpower. Any threat that compromises the sovereignty of any European or EU member state arguably presents a direct threat to Canadian interests. Strategically, then, in the short- and medium-term, it is much more efficient and effective for Canada to incur the financial and political costs of a modest contribution to PESCO to ensure it is a viable initiative that generates collective defence payoffs. The costs and consequences of local and regional instability would be much higher. Thus, support of European defence by third parties has some potential to reinforce European unity.

Third, since the Ogdensburg Declaration of 1938 and the Kingston Dispensation of 1940, the US and Canada have pursued a continental grand strategy with an objective to keep security threats and instability away from North American shores (Leuprecht et al., 2019, p. 121). That explains why the strategic culture of the US and Canada is inherently expeditionary. Canada's grand strategy is premised on two seemingly contradictory dimensions of its strategic culture. The first is that Canada has historically embraced an expeditionary approach when it comes to defence policy and the posture and deployment of Canadian military power. "From Paardeberg to Panjwai," as eminent historians Bercuson and Granatstein (2012, p. 193) have written, "Canadian governments [...] have believed that one of the key missions of the Canadian military is to deploy abroad." These deployments have served the national interest. In imperial wars, world wars, the Cold War and myriad limited conflicts that have characterized the post-Cold War and post 9/11 period, Canada has contributed extremely useful and highly regarded forces. It is up to the efforts of allies to contain global threats and lesser challenges posed by regional instability to the security and stability of the West and, therefore, to Canada. In addition to meeting a common threat, forces have been dispatched overseas to send a message and, by so doing, to guarantee Ottawa "a seat at the table" along with a sense of status and prestige (Leuprecht et al., 2019, p. 125). This expeditionary strategic culture allowed Canada - which neither was regarded, nor saw itself as a great power - to nonetheless, show larger nations (e.g. the UK and the US), international organizations (such as the UN) or allied nations (including the ones across Europe) that Canada is ready and able to step up when military forces are needed to defend allies, deter aggression, and keep or enforce peace. Doing so has won Canada diplomatic recognition, political acceptance, entrée into arrangements, treaties, and alliances that are important to Canada and Canadians - such as the EDF and PESCO and have a voice on how future international policies will be pursued. Were Canada not to take part in such missions abroad, friends and enemies alike would have concluded long ago that Canada is of no consequence, does not deserve to be listened to and ought not to be accorded any favours in bilateral or multilateral negotiations over matters of consequence. This approach to the allied commitments guarantees that Canada "will always prefer to undertake less of an effort than its great-power partners want it to, but not so little as to be eliminated altogether from their strategic decision making" (Haglund and Roussel, 2007, p. 11).

As Europe faces a revived Russian threat, particularly to the "new" allies on its eastern frontier, PESCO has taken on a sense of urgency in the collective defence of the EU's members. But, as in the past, its culmination will entail a good deal of political and 
military uncertainty and complications that will challenge the management and unity of the Union, demanding adjustments and compromises.

European democracies have consistently adopted strategic initiatives, with many focused on military contributions. These contributions are important and required from each member of the EU, their relative size notwithstanding. The EU's engagement with military policy has provided Canada with a security community to which Canada has consistently applied itself to and contributed to in times of need (Leuprecht and Sokolsky, 2019, p. 127).

Nowadays, we are witnessing a resurgent Canadian commitment to Europe, with Canada once again dispatching forces, lending its albeit modest - yet not inconsiderable capabilities and highly sophisticated military expertise in support of missions such as the enhanced Forward Presence to bolster the stability and security of a region that remains essential to Canada's national interests. Ottawa will remain engaged in European securityif two conditions are met. First, as long as the threat persists and, second, as long as the transatlantic Alliance, with its frequent internal disagreements notwithstanding, remains ultimately united in its determination to provide collective security for all its members. This unique combination of flexibility and unity has sustained transatlantic relations and Canada's commitment and ability to contribute to European security whenever and wherever there has been a risk.

\section{Conclusion}

Canada's investment into PESCO comes at a risk. Or, rather, Canada's investment is precisely an effort to manage that risk. Like the US and other NATO member states, Canada has a long-standing interest in the European Union (and its member states) as a more cohesive and capable defence actor, albeit not autarkic. Canada also wants to ensure that European defence remains rooted, first and foremost, in NATO, with the EU contributing to and complementing NATO objectives, rather than consolidating as a competing collective defence actor. The latter eventuality would leave Canada orphaned strategically. Canada is a member of NATO but not of the EU, and its main leverage is through NATO (Haglund, 1990). Nonetheless, Canadian participation in the EDF and PESCO is a way of buying at least some leverage with the EU as well, however limited it is by virtue of Canada's being an outsider to the EU. Participation in PESCO is a way to contain an autarkic conception of "strategic autonomy" that may compete with NATO and instead drive a transatlantic conception of "strategic autonomy" that remains solidly rooted in NATO (Duke, 2019, p.135).

At the same time, PESCO allows Canada to hedge against uncertainties in the transatlantic relationship in terms of the US commitment to NATO, collective defence and the defence of Europe. Canada is capitalizing on broader European interest in defence multilateralism beyond a hub-and-spokes approach to transatlantic security that hinges on Washington. It is also making every effort to ensure that the result is not a competing hub-and-spokes European defence network that hinges on Brussels under disproportionate French influence in the context of a looming Brexit and political and strategic weaknesses in Germany and Italy. Instead, Canada prefers a multiplayer transatlantic and trans-European network to which it is indispensable: a network that reinforces NATO as the primary transatlantic and trans-European collective defence actor and a network that Canada can leverage. 
Third-party participation in PESCO is thus about much more than reaping benefits from defence innovations and economies of scale from defence procurement for a country that is a relative laggard on NATO defence spending. This is a profoundly strategic issue: for Canada and for the EU alike. That is precisely why third-country participation is so contentious. It also explains why the French are particularly sensitive about thirdcountry participation while Germany, the Baltics and the Nordic countries are strongly supportive. Germany in particular was a long-time beneficiary of stability owing to the Canadian military contributions and commitments during the Cold War. The Baltics in general, and Latvia in particular, are now benefitting from Canadian contributions and commitments in a similar fashion (Leuprecht et al., 2019, p. 119).

Interestingly, Germany is the only continental European country that is also a Framework Nation in the enhanced Forward Presence (to Lithuania); as such, Germany appears to have learned a key lesson from Canada on collective defence. Only three of five Nordic countries are NATO members. Nevertheless, all of them are supportive of the third-country participation in PESCO. Arguably, Sweden and Finland understand the risk of not being a member of NATO and thus want to optimize the benefits of non-EU, NATO states member contribution to European defence. To this effect, they have already initiated greater regionalization of Nordic defence cooperation (Forsberg, 2013, 1165). That is, the three Nordic NATO member states support and see the benefits of cooperation with non-NATO member states with which they share regional interests. After all, all five Nordics have vast experience working closely with Canada, since they maintain collaborative relations with Canada in complementary areas such as the Arctic. Finally, the US, may see PESCO as some competition for their own defence innovation and industry at best, and at worst as draining scarce European resources from being invested in the US whilst being patriated to defence innovation across Europe instead. Yet, this gives one more strategic reason for Canadian involvement. The US knows that Canada's collective defence priorities are vested in NATO, yet everyone stands to benefit from a more coherent and cohesive EU defence actor that can support and complement NATO. With the UK set to leave the EU, NATO and EU member states alike have an overarching interest in minimizing the disruption to transatlantic and trans-European security. Prospective third-country participation in PESCO is a ready means to contain and mitigate possible fallout for collective defence.

\section{References}

Börzel, T. A. \& Risse, T., 2000. When Europe Hits Home: Europeanization and Domestic Change. European Integration online Papers, 4(15), p. 3.

Allison, G., 2018. The Myth of the Liberal Order: From Historical Acident to Conventional Wisdom. Foreign Affairs, July/August, 97(4), pp. 124-133.

Biscop, S., 2012. The UK and the European Defense: Leading or Leaving?. International Affairs (Royal Institutue of Internaitonal Affairs 1944-), pp. 1297-1313.

Borzel , T. A. \& Risse, T., 2003. Conceptualising the domestic impact of Europe. In: K. Featherstone \& C. M. Radaelli, eds. The Politics of Europeanization. Oxford: Oxford University Press, pp. 50-81.

Börzel, T. A. \& Panke, D., 2016. Europeanization. In: M. Cini, ed. European Union Politics. s.l.:Oxford University Press, pp. 114 - 120.

Brunet-Jailly, E., Achim, H. \& Amy Verdun, 2018. European Union Governance and Policy Making: A Canadian Perspective. Toronto: University of Toronto Press. 
Brzozowski, A., 2019. Pentagon warns EU against blocking US firms from defence fund. [Online] Available at: https://www.euractiv.com/section/defence-and-security/news/pentagon-warns-euagainst-blocking-us-firms-from-defence-fund/

[Accessed 24 November 2019].

Canada, G. o., 2016. Strategic Partnership Agreement between Canada, of the One Part, and the European Union and its Member States, of the Other Part, Ottawa: Government of Canada.

Canada, G. o., 2018. Joint Declaration of the Canada-EU Strategic Partnership Agreement Joint Ministerial Committee, Montréal: Government of Canada.

Colby, E. A. \& Mitchell, W. A., 2020. The Age of Great-Power Competition: How the Trump Administration Refashioned American Strategy. Foreign Affairs, January/February.

Council of the Euroepan Union, April 18, 2019. European Parliament legislative resolution of 18 April 2019 on the proposal for a regulation of the European Parliament and of the Council establishing the European Defence Fund, Brussels: European Parliament.

Council of the European Union , 2018. Council Decision of 6 March 2019 Establishing the list of projects to be developed under PESCO, Brussels: European Union.

Cowles, M. G., Caporaso, J. \& Risse, T., 2001. Transforming Europe: Europeanization and Domestic Change. 1st ed. New York: Cornell University Press.

Derrow, J., Leuprecht, C. \& Sokolsky, J., 2017. Canada's Enhanced Forward Presence in the Baltics: An Enduring Commitment to Transatlantic Security. International Journal, 74(1), pp. 118-128.

Diez, T., Stetter, S. \& Albert, M., 2006. The European Union and border conflicts: the transformative power of integration. International Organization, pp. 563-593.

Dombrowski, P. \& Reich, S., 2018. Beyond the Tweets: President Trump's Continuity in Military Operations. Strategic Studies Quarterly, Volume Summer, pp. 56-81.

Duke, S. W., 2019. The Competing Logics of EU Security and Defence. Survial, pp. 123-142.

Emerson, M., 2004. Europeanisation \& Conflict Resolution Testing an Analytical Framework, Brussels: CEPS Policy Brief,

European Central Bank, 2017. Financial integration in Europe, Frankfurt: European Central Bank.

European Commission , 2019. European Defence Fund. [Online]

Available at: https://ec.europa.eu/commission/news/european-defence-fund-2019-mar-19 en

[Accessed 2019 November 2019].

European Commission , 2019. The European Defense Fund Factsheet. [Online]

Available at: https://ec.europa.eu/docsroom/documents/34509

[Accessed 21 November 2019].

European Defence Agency \& NATO, 2015. To the Cooperation Framework Agreement Between the NATO Counter Improvised Explosive Devices Centre of Excellence, Brussels: European Defence Agency.

European Parliament, 2015. The Western Balkans and EU Enlargement: Lessons learned, ways forward and prospects ahead, Brussels: Policy Department, Directorate-General for External Policies.

European Union , 2018. PESCO Projects. [Online]

Available at: https://www.consilium.europa.eu/media/37028/table-pesco-projects.pdf

[Accessed 24 November 2019]. 
European Union , 2019. Permanent Structured Cooperation - PESCO: Deepening Defence Cooperation Among EU Member States. [Online]

Available at: https://eeas.europa.eu/sites/eeas/files/pesco factsheet november 2019.pdf

[Accessed 24 November 2019].

European Union, 2017. EU-Canada Strategic Partnership Agreement, Brussels: European Union.

Falkner, G., 1998. Political Theory and EU Politics. In: EU Social Policy in the 1990s. New York: Routledge, p. 50.

Featherstone, K. \& Radaelli, C. M., 2003. The Politics of Europeanisation. New York: Oxford University Press.

Fergusson, J., 2015. The NORAD Conundrum: Canada, missile defense, and military space. International Journal, 70(2), pp. 196-214.

Fiott, D., 2018. The Multiannual Financial Framework and European Defence. Intereconomics, p. 311.

Fiott, D., 2018. The Multiannual Financial Framework and European Defence. Intereconomics , p. 311.

Fiott, D., 2019. Defence industry, industrial cooperation and military mobility. In: G. Lindstrom \& T. Thierry, eds. NATO and the EU: The essential partners. Rome: NATO Defence College, pp. 55-64.

Flers, Patrick Müller and Nicole Alecu de, 2009. Applying the Concept of Europeanization to the Study of Foreign Policy: Dimensions and Mechanisms.

Freyburg, T., Lavenex, S., Schimmelfennig, F. \& Skripka, T., 2011. Democracy promotion through through Functional Cooperation? The Case of the European Neighbourhood Policy. Democratization, 18(4), p. 1026-1054.

Freyburg, T., Skripka, T. \& Wetzel, A., 2007. Democracy Between the Lines? EU Promotion of Democratic Governance via Sector-Specific Cooperation. Challenges to Democracy in the 21st, p. 20.

Friis, L. \& Murphy, A., 1999. The European Union and Central and Eastern Europe: Governance and Boundaries. Journal of Common Market Studies, 37(2), p. 211-232.

Government of Canada, 2016. Strategic Partnership Agreement between Canada, of the One Part, and the European Union and its Member States, of the Other Part, Ottawa: Government of Canada.

Government of Canada, 2018. Joint Declaration of the Canada-EU Strategic Partnership Agreement Joint Ministerial Committee, Montréal: Government of Canada.

Grabbe, H., 2006. The EU's Transformative Power: Europeanization through Conditionality in Central and Eastern Europe. New York: Palgave Macmillan.

Graziano, P. \& Vink, M., 2007. Europeanization:New Research Agendas. London: Palgrave Macmillan UK.

Haglund, D. G., 1990. Being There: North America and the Variable Geometry of European Security. International Journal, 46(1), pp. 81-112.

Harmsen, R., 2000. EUROPEANIZATION AND GOVERNANCE: A NEW INSTITUTIONALIST

PERSPECTIVE. [Online]

Available at: http://ceses.cuni.cz/ceses-93-version1-4 22 2.pdf

[Accessed 12 2018]. 
Howell , K., 2002. Developing Conceptualizations of Europeanization and European Integration: Mixing Methodologies. UACES Study Group on the Europeanization of British politics, p. 27.

James, F., 2015. The NORAD Conundrum: Canada, missile defense, and military space. International Journal, 70(2), pp. 196-214.

Jensen , M. D. \& Kristensen, P. M., 2012. The elephant in the room: mapping the latent communication pattern in European Union studies. Journal of European Public Policy , 20(1), pp. 120 .

Ladrech, R., 1994. Europeanization of Domestic Politics and Institutions: The Case of France. Journal of Common Market Studies, 32(1), p. 71.

Lavanex, S. \& Wichmann, N., 2009. The External Governance of EU Internal Security. Journal Of European Integration, 31(1).

Lavenex, S., 2004. EU external governance in 'wider Europe'. Journal of European Public Policy, 11(4), pp. 680-700.

Lavenex, S. \& Schimmelfennig, F., 2011. EU Democracy Promotion in the Neighbourhood: From Leverage to Governance?. Democratization, pp. 885-905.

Lavenex, S. \& UçArer, E. M., 2004. The External Dimension of Europeanization. Cooperation \& Conflict, p. 417-43.

Lété, B., 2019. Cooperation in cyberspace. In: G. Lindstrom \& T. Tardy, eds. NATO and the EU: The essential partners. Rome: NATO Defence College, pp. 33-44.

Leuprecht, C., 2019. North by Far Northwest: Indigenising Regional Policy Innovation in Border Management. In: The North American Arctic: Themes in Regional Security . London: UCL Press, pp. 23-32.

Leuprecht, C. \& Hataley, T., 2019. North by Far Northwest: Indigenising Regional Policy. In: The North American Arctic: Themes in Regional Security. London: Universiy College London, pp. 23-32.

Leuprecht, C. \& Sokolsky, J., 2017. Canada's Enhanced Forward Presence in the Baltics: An Enduring Commitment to Transatlantic Security. Riga, Ministry of Foreign Affairs Republic of Latvia, pp. 118128.

March , G. J. \& Olsen , P. J., 2004. The logic of appropriateness. ARENA Centre for European Stadies.

Maulny, J.-P. \& Di Bernardini, L., 2019. Moving PeSCo forward: what are the next steps?, s.l.: Armament Industry European Research Group.

McDougall, W. A., 1997. Back to Bedrock: The Eight Traditions of American Statecraft. Foreign Affairs, March/April, 76(2), pp. 134-146.

McGowan, L., 2007. Theorising European Integration: revisiting neofunctionalism and testing its suitability for explaining the development of EC competition policy?. European Integration Online Papers, 11(3), p. 2.

Mikkelsen, J. T., 1991. Neo-functionalism: Obstinate or Obsolete? A Reappraisal in the Light of the New Dynamism of the EC. Journal of International Studies, 20(1), pp. 1-22.

Morphet, J., 2017. What Does the EU Do for the UK and the UK for the EU?. In: Beyond Brexit?: How to Assess the UK's Future. Bristol: Bristol University Press, pp. 33-50. 
Müller, P. \& de Flers, N. A., 2009. Applying the Concept of Europeanization to the Study of Foreign Policy: Dimensions and Mechanisms. Institute for European Integration Research, p. 32.

Noutcheva, G. et al., 2004. Europeanization and Secessionist Conflicts: Concepts and Theories. Journal of Ethno Politics and Minority Issues in Europe, Volume 1, pp. 1-35.

Olsen, J. P., 2002. The Many Faces of Europeanization. JCMS, 40(5), pp. 921-952.

Olsen, J. P., 2009. Change and continuity An institutional approach to institutions of democratic government. European Political Science Review, , 1(01), pp. 3-32.

Ozawa, M., 2019. Annex 2. The Alliance Five Years after Crimea: Implementing the Wales Summit Pledges, December, pp. 137-152.

Petrovic, M., 2013. The Democratic Transition of Post-Communist Europe: In the Shadow of Communist Differences and Uneven EUropeanisation. London: The Palgrave Macmillan.

Petrovic, M. \& Klatt, M., 2015. The European Union and its post-communist neighbours: EU enlargement and the European Neighbourhood Policy. In: N. Witzleb, A. A. Martínez \& P. Winand, eds. The European Union and Global Engagement: Institutions, Policies and Challenges. Cheltenham: Edward Elgar Publishing Limited, p. 197-215.

Puchala, D. J., 1971. OF BLIND MEN, ELEPHANTS AND INTERNATIONAL INTEGRATION. Journal of Common Market Studies , p. 267.

Radaelli, C. M., 2000. Whither Europeanization? Concept streching and substantive change. European Integration online papers, 4(8), pp. 6-25.

Radaelli, C. M. \& Exadaktylos, T., 2009. Research Design in European Studies: The Case of Europeanization. Journal of Common Market Studies, Volume 47, p. 507-530.

Radaelli, C. M. \& Featherstone, K., 2003. The Politics of Europeanization. 1 ed. Oxford: Oxford Scholarship Onlin.

Rath, A., 2004. Canada and Development Cooperation. International Journal, 59(4), pp. 853-71.

Risse, T., Caporaso, J. \& Cowles, M. G., 2001. Europeanization and domestic change. In: J. Caporaso \& T. Risse, eds. Transforming Europe: Europeanization and Domestic Change. New York: Cornell University Press, pp. 1-19.

Schimmelfennig , F. \& Sedelmeier, . U., 2004. Governance by conditionality: EU rule transfer to the candidate countries of Central and Eastern Europe. Journal of European Public Policy, pp. 661-679.

Schimmelfennig , F. \& Sedelmeier, U., 2004. Governance by conditionality: EU rule transfer to the candidate countries of Central and Eastern Europe. Journal of European Public Policy, pp. 661-679.

Schimmelfennig, F., 2004. Governance by Conditionality: EU Rule Transfer to the Candidate Countries of Central and Eastern Europe. Journal of European Public Policy 11, pp. 669-687.

Schimmelfennig, F., 2012. Europeanization beyond Europe. Living Reviews in European Governance, 1(7).

Schimmelfennig, F., 2012. Europeanization beyond Europe. Center for Comparative and International Studies, pp. 1-31.

Schimmelfennig, F. \& Scholtz, H., 2007. EU Democracy Promotion in the European Neighborhood: Conditionality, Economic Development, and Linkage. Monreal, s.n., p. 31. 
Sedelmeier, U., 2006. Europeanisation in new member and candidate states. Living Rev. Euro. Gov, p. 23.

Sokolsky, J. J., 2019. The Power and the Burdern (Sharing): The United States and the Future of NATO. In: NATO at 70 Years: Selected Topics in World Security. Toronto: NATO Association of Canada, pp. 5-9.

Sokolsky, J., Leuprecht, C. \& Derow, J., 2019. Canada's Enhanced Forward Presence in the Baltics: An Enduring Commitment to Transatlantic Security. International Journal, 19 March, 74(1), pp. 118128.

Tardy, T., 2018. European defence: what impact for NATO?, Rome: NATO Defense ollege: Research Division.

The Economist , 2019. The Economist. [Online]

Available at: https://www.economist.com/europe/2019/11/07/emmanuel-macron-warns-europenato-is-becoming-brain-dead

[Accessed 16 November 2019].

Tuomas, F., 2013. The Rise of Nordic Defence Cooperation: A Return to Regionalism?. International Affairs (Royal Institute of International Affairs 1944-), 89(5), pp. 1161-181.

Union, E., 2019. Permanent Structured Cooperation (PESCO)'s projects - Overview. [Online] Available at: https://www.consilium.europa.eu/media/41333/pesco-projects-12-nov-2019.pdf [Accessed 22 December 2019]. 


\section{Appendix A: An overview of PESCO projects (European Union, 2018)}

\begin{tabular}{|c|c|c|}
\hline Description & Project & Participating States \\
\hline \multirow[t]{5}{*}{$\begin{array}{l}\text { Training, } \\
\text { Facilities }\end{array}$} & $\begin{array}{lrr}\text { European } & \text { Union } & \text { Training } \\
\text { Mission Competence } & \text { Centre } \\
\text { (EU TMCC) } & \\
\end{array}$ & $\begin{array}{l}\text { Germany, Austria, Czechia, France, Italy, } \\
\text { Ireland, Luxembourg, Netherlands, Romania, } \\
\text { Sweden, Spain }\end{array}$ \\
\hline & $\begin{array}{l}\text { European Training Certification } \\
\text { Centre for European Armies }\end{array}$ & Italy, Greece \\
\hline & $\begin{array}{l}\text { Helicopter Hot and High } \\
\text { Training }\left(\mathrm{H}_{3} \text { Training) }\right.\end{array}$ & Greece, Italy, Romania \\
\hline & Joint EU Intelligence School & Greece, Cyprus \\
\hline & EU Test and Evaluation Centres & France, Slovakia, Spain, Sweden \\
\hline \multirow{6}{*}{$\begin{array}{l}\text { Land, } \\
\text { Formations, } \\
\text { Systems }\end{array}$} & $\begin{array}{l}\text { Deployable Military Disaster } \\
\text { Relief Capability Package }\end{array}$ & Italy, Austria, Croatia, Greece, Spain \\
\hline & Armoured Infantry Fighting & Italy, Greece, Slovakia \\
\hline & $\begin{array}{ll}\begin{array}{l}\text { Indirect } \\
\text { (EuroArtillery) }\end{array} & \text { Sire }\end{array}$ & Slovakia, Hungary, Italy \\
\hline & $\begin{array}{lcc}\text { EUFOR } & \text { Crisis } & \text { Response } \\
\text { Operation Core (EUFOR CROC) }\end{array}$ & EUFOR Crisis Response \\
\hline & $\begin{array}{l}\text { Integrated Unmanned Ground } \\
\text { System (UGS) }\end{array}$ & $\begin{array}{l}\text { Estonia, Belgium, Czechia, Finland, France, } \\
\text { Germany, Hungary, Latvia, Netherlands, } \\
\text { Poland, Spain }\end{array}$ \\
\hline & $\begin{array}{l}\text { EU Beyond Line Of Sight } \\
\text { (BLOS) Land Battlefield Missile } \\
\text { Systems }\end{array}$ & France, Belgium, Cyprus \\
\hline \multirow[t]{4}{*}{ Maritime } & $\begin{array}{lrr}\text { Maritime } & \text { (semi-) } & \text { Autonomous } \\
\text { Systems } & \text { for } & \text { Mine } \\
\text { Countermeasures (MAS MCM) }\end{array}$ & $\begin{array}{l}\text { Belgium, Greece, Latvia, Netherlands, Poland, } \\
\text { Portugal, Romania }\end{array}$ \\
\hline & $\begin{array}{llr}\begin{array}{l}\text { Harbour } \\
\text { Surveillance } \\
\text { (HARMSPRO) }\end{array} & \text { and } & \text { Maritime } \\
\text { Protection }\end{array}$ & Italy, Greece, Poland, Portugal \\
\hline & $\begin{array}{lll}\text { Upgrade } & \text { of } & \text { Maritime } \\
\text { Surveillance } & & \\
\end{array}$ & $\begin{array}{l}\text { Greece, Bulgaria, Croatia, Cyprus, Ireland, } \\
\text { Italy, Spain }\end{array}$ \\
\hline & $\begin{array}{lr}\text { Deployable } & \text { Modular } \\
\text { Underwater } & \text { Intervention } \\
\text { Capability Package (DIVEPACK) }\end{array}$ & Bulgaria, France, Greece \\
\hline \multirow[t]{3}{*}{ Air, Systems } & $\begin{array}{l}\text { European Medium Altitude } \\
\text { Long Endurance Remotely } \\
\text { Piloted Aircraft Systems - } \\
\text { MALE RPAS (Eurodrone) }\end{array}$ & Germany, Czechia, France, Italy, Spain \\
\hline & $\begin{array}{l}\text { European Attack Helicopters } \\
\text { TIGER Mark III }\end{array}$ & France, Germany, Spain \\
\hline & $\begin{array}{l}\text { Counter Unmanned } \\
\text { System (C-UAS) }\end{array}$ & Italy, Czechia \\
\hline \multirow[t]{4}{*}{ Cyber, C4ISR } & $\begin{array}{l}\text { European Secure } \text { Software } \\
\text { defined Radio (ESSOR) }\end{array}$ & $\begin{array}{l}\text { France, Belgium, Finland, Germany, Italy, } \\
\text { Netherlands, Poland, Portugal, Spain }\end{array}$ \\
\hline & $\begin{array}{l}\text { Cyber Threats and Incident } \\
\text { Response Information Sharing } \\
\text { Platform }\end{array}$ & $\begin{array}{l}\text { Greece, Austria, Cyprus, Hungary, Italy, } \\
\text { Portugal, Spain }\end{array}$ \\
\hline & $\begin{array}{l}\text { Cyber Rapid Response Teams } \\
\text { and Mutual Assistance in Cyber } \\
\text { Security }\end{array}$ & $\begin{array}{l}\text { Lithuania, Croatia, Estonia, Finland, Italy, } \\
\text { Netherlands, Poland, Romania }\end{array}$ \\
\hline & $\begin{array}{l}\text { Strategic Command and Control } \\
\text { (C2) System for CSDP Missions } \\
\text { and Operations }\end{array}$ & $\begin{array}{l}\text { Spain, France, Germany, Italy, Luxembourg, } \\
\text { Portugal }\end{array}$ \\
\hline
\end{tabular}




\begin{tabular}{|c|c|c|}
\hline & $\begin{array}{lr}\text { European High } & \text { Atmosphere } \\
\text { Airship Platform } & \text { (EHAAP) - } \\
\text { Persistent } & \text { Intelligence, } \\
\text { Surveillance } & \text { and } \\
\text { Reconnaissance (ISR) Capability }\end{array}$ & Italy, France \\
\hline & $\begin{array}{l}\text { One Deployable Special } \\
\text { Operations Forces (SOF) } \\
\text { Tactical Command and Control } \\
\text { (C2) Command Post (CP) for } \\
\text { Small Joint Operations (SJO) - } \\
\text { (SOCC) for SJO }\end{array}$ & Greece, Cyprus \\
\hline & $\begin{array}{lr}\text { Electronic Warfare } & \text { Capability } \\
\text { and Interoperability Programme } \\
\text { for Future Joint Intelligence, } \\
\text { Surveillance } & \text { and } \\
\text { Reconnaissance } & \text { (JISR) } \\
\text { Cooperation } & \\
\end{array}$ & Czechia, Germany \\
\hline \multirow[t]{7}{*}{$\begin{array}{l}\text { Enabling, } \\
\text { Joint }\end{array}$} & European Medical Command & $\begin{array}{l}\text { Germany, Belgium, Czechia, France, Italy, } \\
\text { Netherlands, Romania, Slovakia, Spain, } \\
\text { Sweden }\end{array}$ \\
\hline & $\begin{array}{l}\text { Network of logistic Hubs in } \\
\text { Europe and support to } \\
\text { Operations }\end{array}$ & $\begin{array}{l}\text { Germany, Belgium, Bulgaria, Croatia, Cyprus, } \\
\text { France, Greece, Hungary, Italy, Lithuania, } \\
\text { Netherlands, Poland, Slovenia, Slovakia, Spain }\end{array}$ \\
\hline & Military Mobility & $\begin{array}{l}\text { Netherlands, Austria, Belgium, Bulgaria, } \\
\text { Croatia, Czechia, Cyprus, Estonia, Finland, } \\
\text { France, Germany, Greece, Hungary, Italy, } \\
\text { Latvia, Lithuania, Luxembourg, Poland, } \\
\text { Portugal, Romania, Slovenia, Slovakia, Spain, } \\
\text { Sweden }\end{array}$ \\
\hline & $\begin{array}{l}\text { Energy } \text { Operational Function } \\
\text { (EOF) }\end{array}$ & France, Belgium, Italy, Spain \\
\hline & 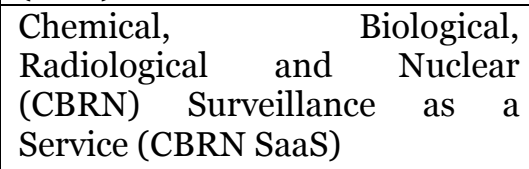 & Austria, Croatia, France, Hungary, Slovenia \\
\hline & Co-basing & $\begin{array}{l}\text { France, Belgium, Czechia, Germany, } \\
\text { Netherlands, Spain }\end{array}$ \\
\hline & $\begin{array}{l}\text { Geospacial, Meteorological and } \\
\text { Oceanographic (GeoMETOC) } \\
\text { Support Coordination Element } \\
\text { (GMSCE) }\end{array}$ & $\begin{array}{l}\text { Germany, Austria, France, Greece, Portugal, } \\
\text { Romania }\end{array}$ \\
\hline \multirow[t]{2}{*}{ Space } & $\begin{array}{l}\text { EU Radio Navigation Solution } \\
\text { (EURAS) }\end{array}$ & $\begin{array}{l}\text { France, Belgium, Germany, Italy, Poland, } \\
\text { Spain }\end{array}$ \\
\hline & $\begin{array}{l}\text { European Military } \begin{array}{r}\text { Space } \\
\text { Surveillance }\end{array} \text { Awareness } \\
\text { Network (EU-SSA-N) }\end{array}$ & Italy, France \\
\hline
\end{tabular}




\section{Appendix B: An overview of PESCO projects added as of November 2019 European Union, 2019)}

\begin{tabular}{|l|l|l|}
\hline Description & Project & Participating States \\
\hline \multirow{4}{*}{ Training, } & $\begin{array}{l}\text { Integrated European Joint Training and } \\
\text { simulation Centre (EUROSIM) }\end{array}$ & $\begin{array}{l}\text { Hungary, France, } \\
\text { Germany, Poland, Slovenia }\end{array}$ \\
\cline { 2 - 3 } & EU Cyber Academia and Innovation Hub & Portugal, Spain \\
\cline { 2 - 3 } & $\begin{array}{l}\text { Special Operations Forces Medical Training } \\
\text { Centre (SMTC) }\end{array}$ & Poland, Hungary \\
\cline { 2 - 3 } & CBRN Defence Training Range (CBRNDTR) & Romania, France, Italy \\
\cline { 2 - 3 } & $\begin{array}{l}\text { European Union Network of Diving Centres } \\
\text { (EUNDC) }\end{array}$ & Romania, Bulgaria, France \\
\hline Maritime & $\begin{array}{l}\text { Maritime Unmanned AntiSubmarine System } \\
\text { (MUSAS) }\end{array}$ & $\begin{array}{l}\text { Portugal, France, Spain, } \\
\text { Sweden }\end{array}$ \\
\cline { 2 - 3 } & European Patrol Corvette (EPC) & Italy, France \\
\hline Air, Systems & Airborne Electronic Attack (AEA) & Spain, France, Sweden \\
\hline Eyber, C4ISR & $\begin{array}{l}\text { Cyber and Information Domain Coordination } \\
\text { Center (CIDCC) }\end{array}$ & $\begin{array}{l}\text { Germany, Czechia, } \\
\text { Hungary, Netherlands, } \\
\text { Spain }\end{array}$ \\
\cline { 2 - 3 } & $\begin{array}{l}\text { Timely Warning and Interception with Space- } \\
\text { based TheatER surveillance (TWISTER) }\end{array}$ & $\begin{array}{l}\text { France, Finland, Italy, } \\
\text { Netherlands, Spain }\end{array}$ \\
\cline { 2 - 3 } & $\begin{array}{l}\text { Materials and components for technological } \\
\text { EU competitiveness (MAC-EU) }\end{array}$ & $\begin{array}{l}\text { France, Portugal, Romania, } \\
\text { Spain }\end{array}$ \\
\cline { 2 - 3 } $\begin{array}{l}\text { EU Collaborative Warfare Capabilities } \\
\text { (ECoWAR) }\end{array}$ & $\begin{array}{l}\text { France, Belgium, Hungary, } \\
\text { Romania, Spain, Sweden }\end{array}$ \\
\cline { 2 - 3 } & $\begin{array}{l}\text { European Global RPAS Insertion Architecture } \\
\text { System }\end{array}$ & Italy, France, Romania \\
\hline
\end{tabular}

